\title{
Kuradite vägitegudest Äänisjärve idarannikul $^{1}$
}

\begin{abstract}
Enn Ernits
Teesid: Artiklis käsitletakse Äänisjärve kaljuraiendite ja nende ühe asupaiga - Bessov Nossi neeme - seost viie looga kuraditest. Enamasti on tegu etioloogiliste muistendite ümberjutustustega. Lood käsitlevad kuradite kokkupõrkeid ristiusuga, nende põgenemist ja hukku. Ühes seletavas loos kajastub kujutelm sellest, kuidas kurat võib pugeda kaaneta ja ristimärgita nõusse. Kohalike elanike seoste hägunemisel petroglüüfidega ja ristiusu mõjul hakati neid pidama kuradite kätetööks. Kirjutises üritatakse kummutada krestomaatilist arvamust, et ristimärgi on Bessi neeme antropomorfile ja ühele luigekujutisele raiunud Muromi kloostri mungad.
\end{abstract}

Märksõnad: kaljutaie, Karjala, kurat, muistendid, ristiusk

Karjalas Äänisjärve idarannikul paarikümne kilomeetri pikkusel alal leidub üle 1000 petroglüüfi ehk kaljuraiendi. Need on tehtud põhiliselt nooremal kiviajal. Kaljuraiendite valmistajateks peetakse läänemeresoomlaste esiisasid, kes viljelesid toona kammkeraamikat. Ajaloolisel epohhil on Äänisjärve taga elanud peamiselt etnilisi venelasi, kuid keelejoonte, kohanimede jm põhjal otsustades on nad venestunud läänemeresoomlased, kõige tõenäolisemalt vepslaste järglased.

Äänisjärve kaljuraiendid avastas XIX sajandi keskpaiku teadusele toonane Peterburi Teaduste Akadeemia mineraloogia muuseumi konservaator, hilisem Tartu ülikooli professor Constantin Grewingk (1819-1887). Esimesed neemed, mille petroglüüfidest teadusmaailm kuulda sai, olid Bessov ja Peri Nos. Need paiknevad peaaegu Petroskoi vastas Äänisjärve idarannikul (joonis 1). Mõlemad neemed on seotud lugudega kuraditest. Siinkirjutajale on teada viis lugu, millest neli on säilinud vaid ümberjutustusena. Neid on varem siinkirjutaja ingliskeelsetena taasesitanud ja lühidalt kommenteerinud (vt Poikalainen, Ernits 1998: 42). 
Joonis 1. Peri ja Bessi neem Äänisjärve idarannikul (Ravdonikas 1936: 122 järgi).
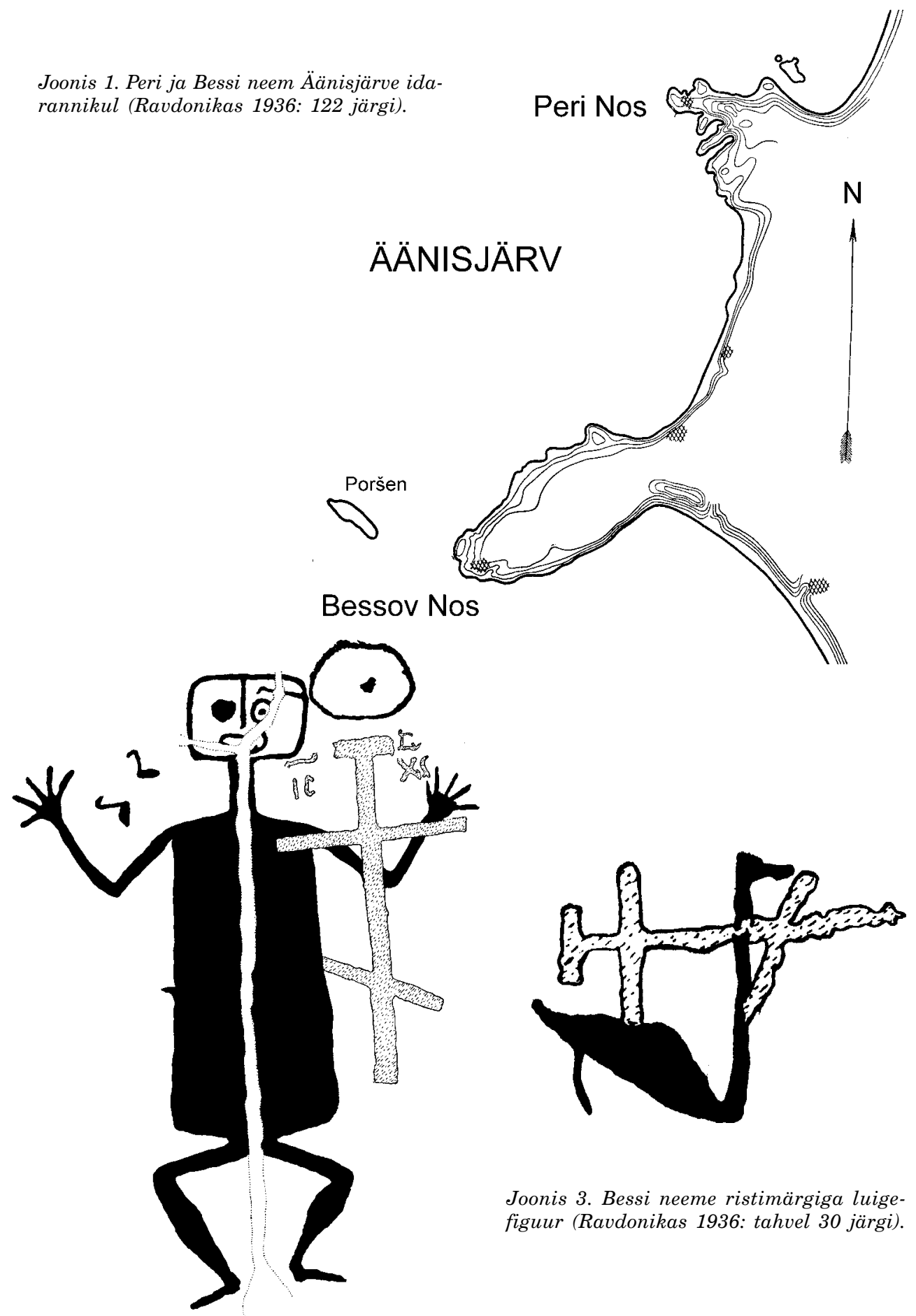

Joonis 2. Bessi neeme suur inimlaadne kujutis (Ravdonikas 1936: tahvel 29 järgi). 


\section{Tülid ja lahkumine}

(1) Rahvasuus käibib muistend, nagu oleksid siin paljude-paljude aastate eest pesitsenud kurat ja ta abikaasa (Bess ja Bessihha) ning jä̈̈dvustanud kaljusse oma kohaloleku imepäraste figuuridega. Siis olevat aga kehastunud Kristus ning saabunud tõeline usk ja kuradipiltidele raiutud ristid sisse. Jalamaid pidid kurivaimud taganema, kuid tahtsid enne, kui teele asusid, siit ühe mälestuse, s.t kaljupanga neile armsast paigast kaasa võtta, ent langesid selle kavatsuse juures koos praegugi näidatava kaljurahnuga järve ja uppusid (Grewingk 1855: 98).

Kõnealust müüdivarianti pole peale Äänisjärve petroglüüfide avastaja hiljem keegi vahendanud. Siinpuhul on tegu etioloogilise muistendiga, mis seletab 1) kaljuraiendite teket mäletamatutel aegadel ja 2) Bessi neeme jätkuna selle lähedal asuva Poršeni nimelise pisikese taimkatteta kaljusaare sündi. Paljude, paljude aastate eest tähistab müütilist aega enne paikkonna ristiusustamist. Ida-Karjalas saadi nn paganlusest jagu 13. sajandiks (Pulkin jt 1999: 30).

Bessi neemel leidub suurkujutiste triaad (Ravdonikas 1936: 93-94). Sügava lõhe ümber on raiutud hiiglasuur (ligemale 2,5 m pikkune) inimlaadne ehk antropomorfne olend, mida kutsutakse ka Kuradiks (joonis 2). Temaga paralleelsed on sama suur säga- ja saarmalaadne kujutis. Antropomorfi vasakule käele, mida ilmselt usuti paha tegevat, raiuti kristlaste poolt õigeusurist ja selle juurde Kristuse nomogramm IC-XC lühendusmärkidega. Rist on tehtud ka ühele luigefiguurile (joonis 3). Veelinnukujutised on Äänisjärve kaljudel erakordselt sagedad, moodustades $44 \%$ petroglüüfide koguarvust (Poikalainen 2004: 23). Veelindudel oli muistsete äänisjärvelaste uskumustes ilmselt oluline koht, mida näitab ühelt poolt nende rohkus, teisalt aga "ristimiseks" just luigekujutise valimine.

Suure antropomorfi järgi ongi Bessi neem (Бесов Нос) ja sellel asunud küla saanud oma nime. Tõenäoliselt on vene бec ristiusueelne, seega vanem nimetus kui чёрт, mis tuli Venemaal kasutusel alles 16.-17. sajandil. Sõnal беc on mitu tähendust. Õigeusu kirjasõnas vastab ta kreeka daimonile 'deemon, kurivaim, kes viib inimesi kiusatusse', mis käsitletavas muistendis tuleb vaevalt kõne alla. Vene rahvausundis märkis бec esialgu igasugust väge, mis hiljem konkretiseerus kodu-, metsa-, vee- jt haldjate näol, kuid seostumisel kristlusega hakkas tähistama pahatahtlikke, kurje vaime, kõige sagedamini kuradeid. Peale mainitute märgib бecka ristiusueelseid jumalusi ja iidoleid, samuti ka toonast loodususulist inimest (Sreznevski 1989: 222; Tolstoi 1995: 164; Vlassova 1998: 40 jj; Šaparova 2001: 89 jj). 
Viimati mainitud tähendus langeb ühte eesti Vanapaganaga, sest juba August Kitzberg arvas, et vanapaganad on vanad eestlased, kes ristiusku vastu ei võtnud (Laugaste, Liiv 1970: 25 jj). Sarnasusi on veel teisigi. Ka Vanapagan, kes on puhuti seostunud ristiusu Kuradiga, põgeneb ristiusu märkide eest. Kurat võib uppuda ka eesti muistendis, näiteks Tõllu eest põgenedes. Neil oli kindel asupaik. Nad elavad perekondadena (Laugaste, Liiv 1970: 7, 18, 24, 284, 289, 401; vt $\mathrm{nr} 284,464,623,625)$. Saarte loomist esineb ka eesti lugudes, näiteks olevat Abruka saar tekkinud nõnda, et Vanapagan kiskunud Kuramaa rannast tüki maalahmakat lahti, ujutanud üle Riia lahe Kuressaare poole. Kaljupanga kaasavõtmine mälestuseks tundub olevat originaali moondunud koht.

Mõningast sarnasust on käsitletaval lool soome muistenditega, milles hiidude elukohaks on teiste hulgas ka kaljud, hiiglased pagevad kirikukella lööke kuuldes; saared võivad tekkida liiva või kivide mahapillamisel (Jauhiainen 1999: 274, 285, 294). Paraku pole siinkirjutaja vaatamata senisele otsingutele leidnud karjalaste ja vepslaste hiiumuistendeid. Vene sõna on laenatud karjala keelde muide mitmel kujul, nagu biesa, biessu, piessa jt (Koponen 1993: 266, 267).

Karjala kodu-uurija Ivan Mullo (1971: 78) on oletanud, et Bessi neeme nimetus võis algselt olla mitte vene-, vaid saamikeelne ning tähendada mingit jumalust. Autor viitas siinjuures vanaaegses kirjanduses leiduva pühakoha nimetusele bessousing, mis seletuvat sellega, et igal saami jumalusel olevat olnud oma püha elamu. Seda oletust ei saa kummutada ega ka veenvalt tõestada, kuid saami bassi tähendab tõepoolest 'püha' (Sammallahti 1989: 27). Muromi kloostri rajaja Püha Lazari testamendi väitel on saamid kunagi elanud selles kandis (vt Ambrosi 1813: 120, 122). Selge, et kõnealune neem oli muistne pühamu. See võidi välja valida järgmisel põhjusel: Bessi neeme ümbrus on tähelepanuväärne veel sellepoolest, et peaaegu kogu terrass Musta jõe ja järve vahel annab isegi kõige kergemasammulise kõnnaku korral selget heli, mis sarnaneb kaugete kirikukellade helinaga (Šved 1850). Bessi Kuradi kõige tõenäolisemaks loomisajaks loetakse IV aastatuhande keskpaika või lõppu eKr (Stoljar 2002: 89).

Lugejale ehk pakub huvi, kelleks on Bessi neeme Kuradit peetud teaduskirjanduses? Kõik uurijad on teda üksmeelselt hinnanud väga tähtsa olendi kujutiseks. C. Grewingk (1855: 101) pidas seda võimsaks jahipidamis- ja kalapüügijumalaks, kes väljasirutatud kätega tunnistab ta niihästi oma ülemvõimu kõigi kuivamaa ja vete elanike üle kui ka õigust teda ümbritsevatele ohvriandidele. P. Schwedt arvas, et tegu on ülemjumalus Väinämöisega soome mütoloogiast (Šved 1850: 69). A. Linevski (1939: 115) pidas antropomorfi metsa- ja kurja ida- (st maapoolt puhuva) tuule haldjaks, sest see ajavat kala ja rändlinnud kaldast eemale ega lubavat paatidel randuda. K. Lauškini arvates on tegu 
hoopis pahatahtliku Tuonela emandaga (Lauškin 1962: 213 jj). Käesolevate ridade autor on siinpuhul oletanud maaema (Ernits 1987: 82-85). Tänapäeva petroglüfistikas on konkreetsete prototüüpide otsimisest üldiselt loobutud. Märgitagu siinkohal, et A. Stoljar on Bessi triaadi puhul veendunud, et petroglüüfidele eelnesid neemele vertikaalselt paigutatud robustsed puuiidolid (Stoljar 2002: 86-88).

(2) Rahvapärimus edastab selle paiga kohta üsna lihtsakoelise loo. Meeskurat ja naiskurat, ornad abikaasad, elasid oma majapidamisega kalda ääres. Millegipärast kavatses Bess äkki oma maja üle viia kaugemale ning sidudes nööri külge, tassis neeme järve. Ent see ületas tõenäoliselt ta jõu piiri: ta suutis lahti rebida vaid ühe nurga, mis koos temaga kukkuski vette... (Šved 1850: 69; Barsov 1878: 226 < Šved 1850 (Poikalainen \& Ernits 1998 pidas J. Barsovi ekslikult 1. jutu edastajaks); Šaižin 1906: 4; Šidlovski 1914: 3; Slutševski 1897: 391).

Seda lugu on erinevalt eelmisest kirjasõnas palju korratud. Põhjus on ilmselt selles, et vene autorid pole vaevunud C. Grewingki saksakeelse artikliga põhjalikumalt tutvuma, vaid on piirdunud vene keeles avaldatuga. K. Slutševski (1897: 390) variant pärineb tuntud bõliinalauliku I. A. Kasjanovi suust. Viimane oli pärit Petroskoi maakonnast, seega Äänisjärvest lääne poolt. Pole teada, kas see variant on ehtne, sest mainitu oli üks väheseid kirjaoskajaid bõliinalaulikust talupoegi ja võis kõnealuse loo omandada kirjasõna vahendusel.

Äänisjärve petroglüüfide esmakirjeldajate järgi nimetatud antropomorfiga neeme Bessi ehk Krestovõi ('Risti-') neemeks. P. Schwedti järgi olevat seal elanud meeskurat (Bes). Tegelikult pole antropomorfil sugutunnuseid; autor on toetunud vaid venekeelsele meessoost nimetusele. A. Šidlovski (1914: 3) teatel ei ole Krestovõi rahva suus iialgi kasutamist leidnud. Naiskurat (Bessihha) elanud P. Schwedti väitel naabruses asuval Peri neemel, mida kutsutudki Bessihhaks. V. Ravdonikase andmeil kandis Besihha nime just Poršen, mida hiljem pole Besihhana vist enam tuntudki (Ravdonikas 1936: 82; Lauškin 1962: 220). Ega muistenditest maksagi lõplikku tõde otsida. Ka kõnealuses loos, nagu eelmiseski, jääb neemenuki äravedamise põhjus teadmata. Peri neemel eristub seitse neemikut, millesse on raiutud sadu petroglüüfe, kuid ühtki tähelepanuväärset naisekujutist seal ei leidu. Kõnesolevgi muistendivariant kuulub Poršeni saarekese teket seletades etioloogiliste hulka.

(3) Naiskurat elas Peril. Teadlased lõhkasid kaljust suure tüki ja transportisid selle koos naissoost kuradiga Leningradi (Lauškin 1962: 218220; Klein 1967). 
Selles loos mainitakse samuti, et Bessihha elas Peri neemel. Teine lause kajastab tõsiasja, et 1934. aastal lõhati seal arheoloog Fjodor Morozovi juhtimisel suur, petroglüüfidega kaetud kaljulahmakas, mis transporditi järgmisel aastal Ermitaaži (Ermitaaž 1935: 2; Sawwatejew 1984: 52). Aga tähelepanuväärseid naiselaadseid olendeid nn Ermitaaži katusel pole.

Huvitav on arheoloog L. Kleini (1967) kinnitus lastele, et tegelikult pole Bessihhat Peril kunagi olnudki. Ta olevat elanud hoopis Bessi neemel. Bess uppus muistendi kohaselt ning Bessihha jäänud tänaseni kaldale. See olevatki praegune Kurat. Seega mõlemaid, nii Bessi kui ka Bessihhat, võidi kujutleda elamas Bessi neemel.

Pöördume vanema kirjasõna poole. K. Slutševski (1897: 392) kirjutas, et kohalikud elanikud peavad sealseid figuure bessideks, kusjuures kellegi Tjumenevi väitel, kes ise oli Bessi neemel viibinud, äratanud tähelepanu kaks inimlaadset figuuri, millest suurem olnud Kurat. Aga milline on teine figuur? P. Semjonovi kohaleksikonist leiame, et peale suure antropomorfi olevat neeme serva raiutud naisekujutis, samojeedi rõivais (Semjonov 1863: $380 \mathrm{sub}$ Бесов ноc). Ilmselt pidas märksõna autor silmas mingit kasukalaadset riideeset. Oletatavasti võis siinpuhul tegu olla hiigelsuure sägakujutisega, millel on nagu antropomorfilgi kujutatud silmad. Raiend oli ehk kunagi osaliselt sammaldunud ja meenutas antropomorfi ka kohalikele elanikele. Halvale nähtavusele XIX sajandi keskpaigas paistab osutavat tõik, et sägakujutisest on C. Grewingki ja P. Schwedti joonistel näidatud vaid sabaosa.

\section{Roopide ja pannide valmistamine}

(4) I. Smirnova kordab oma vanaema juttu 1940. aastal: "Palju olen kuulnud Bessov Nossist. Vanaema rääkis muinaslugusid sealsetest kuraditest. [Sellest], miks seal valmistati suurel hulgal praepanne ja ahjuroope, kuidas kurat taltsutati risti abil. Ta jutustas ka sellest külast. Pärast seda, kui kuradid lahkusid, tollest ajast peale asusid sinna elama põgenikud, ent nad olid teist usku, vana usku, ja elasid seal kaua" (Severnõje 1978: 56).

Selle loo kommentaaris arvatakse õigusega, et muistendis on segunenud hämarad mälestused põliselanikest, kelle kuju on transformeerunud fantastilisteks bessideks (võimalik, et sealsete petroglüüfide mõjul) ning XVII sajandil sinna kanti põgenenud vanausulistest (Severnõje 1978: 175).

Praepannide all tuleb mõista ühe või mitme haruga ümmargusi kosmomorfe, täpsemini nn solaarmärke, ahjuroopide all aga saualaadseid ehk skapanomorfseid figuure (joonis 4). Kumbagi rühma ei esine Bessi neemel, küll aga Peri ja 


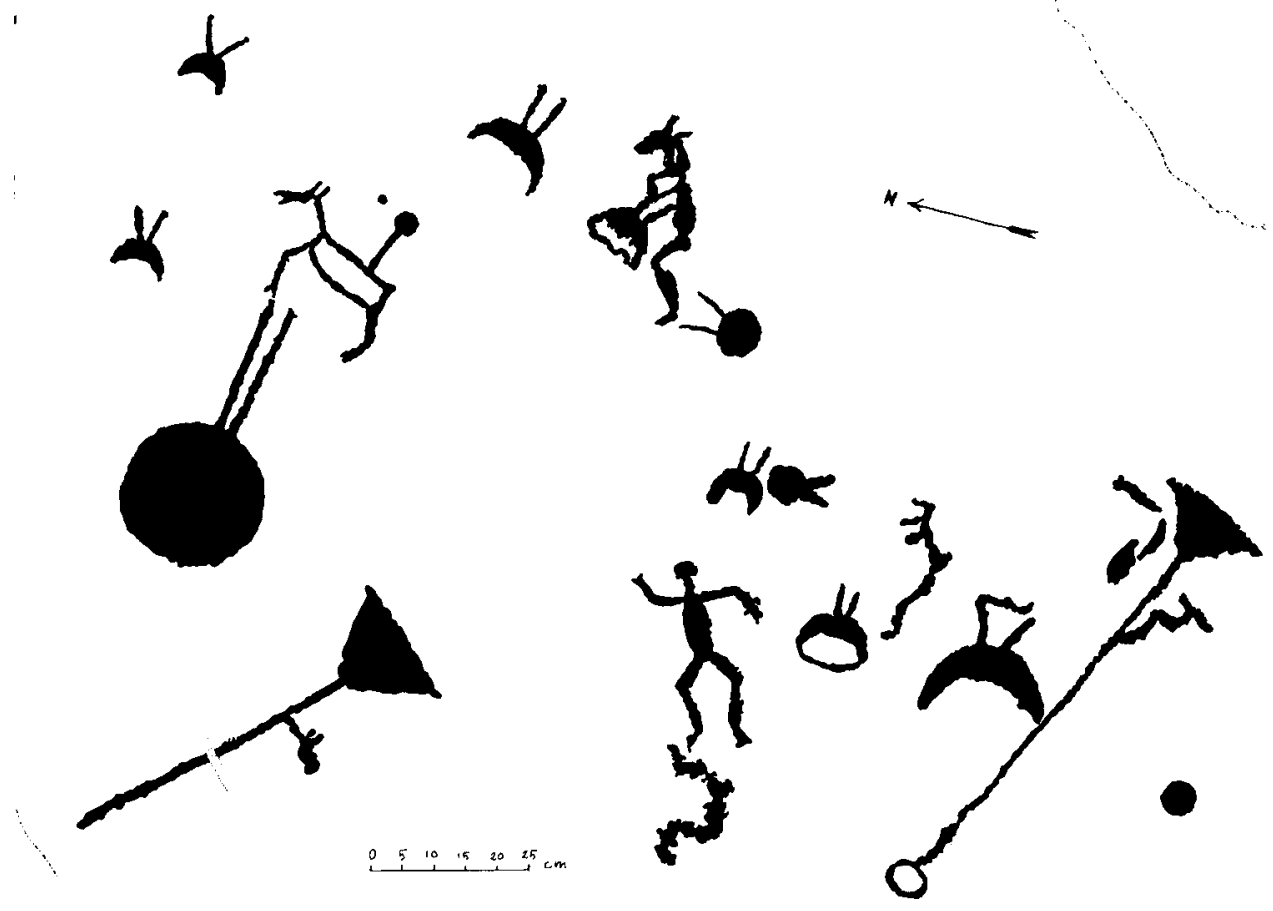

Joonis 4. Peri VI neemiku raiendite seas on eriti palju skapano- ja kosmomorfe (Ravdonikas 1936: tahvel 20 järgi).

Joonis 5. Bieggagalles saami šamaanitrummil (Autio 1981: 149 järgi).

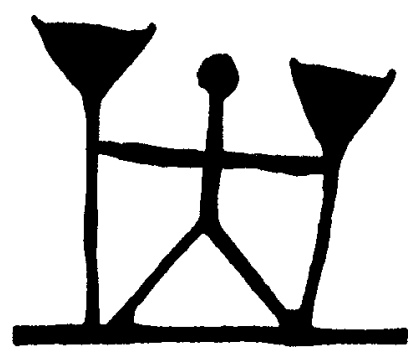

Karitski neemikutel, kuid tekstist ei ilmnegi, kas juttu on Bessi neemest või samanimelisest külast ja selle lähiümbrusest.

Huvituseta pole märkida, et kosmomorfide esinemus Äänisjärve kaljudel on veelinnukujutiste järel teisel kohal, moodustades petroglüüfide koguarvust $13 \%$, kusjuures kosmomorfide hulgas on päikest või täiskuud meenutavaid raiendeid 66\% (Poikalainen 2004: 25). Ent kolmnurkse otsaga ja väikese põdrakujutisega saualaadsed figuurid on suhteliselt haruldased. Nii päikeselaadseid raiendeid ehk heliomorfe ja skapanomorfe on peaaegu 170 aasta vältel identifitseeritud (samuti ka tõlgendatud) väga erinevalt (vt Poikalainen \& Ernits 1998: 34). Karjala kaljutaideuurija Eero Autio on neid seostanud saamide tuule- ja ilmahaldja Bieggagallese 'Tuulevana' kujutisega nõiatrummidel (Autio 1981: 148-149; joonis 5). 


\section{Kurat taaripotis}

(5) Kurat ronis suurde savist potti, et juua käärivat taari. Potissepp kattis poti kaanega. Taar kääris edasi ja lõi potikaane lahti, kurat lendas koos kääriva taariga Ä̈̈nisjärve kaljule, kus tema kujutis on säilinud tänini (Oparin 1978: 48).

Selle huvipakkuva loo on pajatanud Anisja Ivanovna Karpovo külast Pudoži maakonnas. Tegu on taas etioloogilise muistendiga, mis selgitab, kuidas tekkis suure Bessi antropomorf. Venelased teevad tõepoolest taari ja õlut mahukas, kuni 20-liitrises savipotis, mida nimetatakse ilmselt turgi päritolu sõnadega kortšak ja kortšaga (Zelenin 1991: 138, 155). Loost jäi esialgu mulje, et seal räägitakse rumalast kuradist, kuid see osutus ekslikuks. Tegelikult kajastab see Venemaal levinud kujutelma, mille kohaselt kurat ronib kaaneta ja ristimärgita nõusse ning põhjustab inimesele õlle või taari joomisel haigust või isegi surma (Vlassova 1998: 45; Šaparova 2001: 93).

See lugu on põneva taustaga. Allikaks peetakse talmudis leiduvat legendi, kuidas kuningas Saalomon olevat saanud võitu kurivaimudest. Lugu levis Lääne maailmast Bütsantsi kaudu Venemaale, kus see ilmneb kõige paremini Novgorodi esimese peapiiskopi Ioanni (surn 1186) ja Rostovi Avrami eluloos ning rahvalugudes (Pomerantseva 1975: 133). Pühakueluloos räägitakse kõigepealt munk Ioannist, keda ühel öösel kiusanud kurat:

Въ един убо от дний святому по обычаю своему в ложницы своей молитвы нощныя свершаюшу. Имеяше же святый сосуд с водою стоящь, из него умывашеся. И слыша в сосуде оном некотораго поропюща в воде, и прииде скоро святый, и уразуме бесовьское мечтание. И, сотворь молитву, и огради сосуд крестом и запрети бесу'Ühel päeval sooritas pühamees tavakohaselt oma magamisruumis ööpalvet. Sealsamas seisis veega püha nõu, millest end pesi. Ja kuulnud selles nõus mingisugust solistamist, tuli püha mees kohe ligi ja tabas ära saatanliku lummuse. Ta tegi palvetades ristimärke ja sulges kuradi nõusse' (Dmitrijev 1990: 227-228).

Kurat anus enda väljalaskmist. Munk tegi seda, kuid nõudis, et kurat sõidutaks ratsahobusena ta ühe öö jooksul Novgorodist Jeruusalemma ja tagasi. Teises samalaadses legendis on juttu sellest, kuidas arhimandriit sulges kuradi ristimärgiga pesunõusse ning pääsemiseks tõotas kurat toimetada kõrge vaimuliku hommikuse ja päevase liturgia vahel Jeruusalemma.

Ka rahvalugusid on mitmesuguseid. Ühes neist jutustatakse, kuidas kuratolevat roninud saviastjasse, kui eit hakanud tainast sõtkuma. Kui naine lõi nõu juures ristimärke ette, siis kurat ei olevat sealt suutnud enam kolme päeva jooksul välja ronida. Teises loos kõneldakse, kuidas eit jättis taari joo- 
ma hakates ristimärgi tegemata ja kurat sattus kõhtu, kus teda piinas terve elu (Pomerantseva 1975: 134, 139).

Näib, et Äänisjärve tagune lugu on tekkinud käsitletute baasil. Siin on segunenud kuradi anumasse sattumine ja Jeruusalemma sõit, mistõttu on tekkinud kõnealune etioloogiline muistend. Kuna tegu on nõukogudeaegse lühikese ümberjutustusega, siis me ei saa teada, kas seal esines ka kristlikke elemente. Praegusel kujul kajastab ta lihtsat talupoeglikku maailmavaadet. Siinkohal lisame, et pühakueluloo põhjal kuulutati Ioann peapiiskopiks Novgorodist nelja kilomeetri kaugusel paiknevas Püha Georgi (Jurjevi) kloostris, mille alluvusse kuulus vanasti ka Äänisjärve taguseid alasid. Seega pole kahtlust, et see pühalugu oli omal ajal sealse rahva seas tuntud.

\section{Kes taltsutasid Kuradi?}

C. Grewingk (1855: 103) oletas, et Seevastu on palju tõenäolisem, et need ristid on vihatud kujutistele raiunud toonase, Bessi neemest 25 versta lõuna pool asuva Muromi neemel asunud ja enne Solovetskit rajatud kloostri mungad; see peaks langema XIV sajandi algusse (kloostri ajaloo kohta vt Petrov 1886). Muromi kloostri asutaja Lazari testamendis räägitakse tõepoolest, et klooster on rajatud XIV sajandil (Ambrosi 1813: 129). Teisalt peetakse seda ürikut hilisemaks, ent selleski osas pole teadlased ühel meelel. Testament võivat pärineda kas XV sajandi lõpust, järgmise aastasaja algusest või isegi XVII saj teisest poolest (Krušelnitskaja 1996: 117). C. Grewingki asjakohast oletust on oma töödes kriitilise meeleta korranud peaaegu kõik hilisemad uurijad (nt Ravdonikas 1936: 31-32, 94; Sawwatejev 1984: 66). Risti raiumise XIV aastasajal võttis Bessi antropomorfi vanuse määramisel mikroerosiooni meetodil aluseks ka Austraalia kaljutaideuurija R. G. Bednarik (1992).

Olgu, kuidas lugu kronoloogiaga on. Siiski on vähe tõenäoline, et Bessi kuradi "taltsutasid" Muromi kloostri mungad, sest asjaomane kant, teiste hulgas ka Šala Lunastaja (Spasski) pogosti Besov Nossi küla, kuulus vanasti hoopis Tartu vallutamise aastal (1030) rajatud ja juba eespool mainitud Novgorodi Jurjevi kloostrile. Kuna Novgorod asus üsna kaugel, siis tekib küsimus, kas ikka nii kaugelt käidi Karjala kaljudesse riste tegemas. Ent 1505. aastal mainiti Jurjevi kloostri alluvuses olevat Šala mungakloostrit, mille rajamise aega pole suudetud selgitada, kuid millest 1628. aastal räägiti kui minevikus eksisteerinust. 1537. aastal mainiti Šalas pogostikirikut ja 1628. aastal Nigižma (Negižma) kirikut. Mõlemad asusid Bessov Nossi külast samuti paarikümne kilomeetri kaugusel, nagu Muromi kloostergi. Nigižma kiriku alla jäi XVII sajandil ka Bessov Nossi pooltühjaks jäänud küla, kuid 1902. aastal loendati seal 14 talu ja 50 meessoost isikut, seega üle 100 elaniku (Šaižin 1906: 2, 9, 17, 
18, 30, 32; Pulkin jt 1999: 47). Küla tunnistati Nõukogude võimu ajal perspektiivituks ja likvideeriti 1960. aastatel.

Seega oli kirikuvõimudel eri aegadel mitu võimalust teha Bessi neemele ristikujutisi. Väga tõenäoliselt võis see toimuda pärast 1534. aastat, mil Novgorodi peapiiskop Makari andis välja üriku jumalasulastele paganlike kommete täielikuks väljajuurimiseks Ingerimaal ja Karjalas (vt Geiman 1941: 128130). Taolise sisuga kirju saatsid vaimulikele Novgorodi peapiiskopid ka 1548. ja 1595. aastal (Pulkin jt 1999: 43).

\section{Kommentaar}

${ }^{1}$ Kirjutis kujutab endast Eesti Akadeemilise Usundiloo Seltsi konverentsil (Tartu, 26. mail 2007) peetud samanimelise ettekande süvendatud varianti.

\section{Allikad ja kirjandus}

\section{Käsikirjalised allikad}

Ermitaaž 1935 = Государственный Эрмитаж. ОИПК. Коллекция № 1509. Неолитические изображения (Петроглифы). Онежское озеро.

\section{Kirjandus}

Ambrosi 1813 = Амбросий. Нстория Российской иерархии 5. Москва.

Autio, Eero 1981. Karjalan kalliopiirokset. Helsinki: Otava.

Barsov 1878 = Барсов, Е. В. Об олонецких древностях. Древности: Труды Московского археологического общества $7_{3}, \mathrm{lk} 213-233$.

Bednarik, R. G. 1992. A new method to date petroglyphs. Arhaeometry 34, lk 279-291.

Dmitrijev 1990 = Дмитриев, Л. А. (koost) Литература древней Руси. Хрестоматия. Под редакцией Д. С. Лихачева. Москва: Высшая школа.

Ernits, Enn 1987. Maast ja taevakehadest Äänisjärve kaljuraienditel. Tartu tähetorni kalender 1988. aastaks. Tallinn: Valgus, lk 82-89.

Geiman 1941 = Гейман, В. Г. (toim) Материалы по истории Карелии XII-XVI вB. Петрозаводск: Государственное издательсво КФССР.

Grewingk, C. 1855. Über die in Granit geritzten Bildergruppen am Ostufer des OnegaSees: (Lu le 5 mai 1854). - Bulletin de la Classe des Sciences historiques, philologiques et politiques de l'Académie Impériale des Sciences de Saint-Pétersbourg, 12 $7 / 8$, 97-103.

Jauhiainen, Marjatta 1999. Suomalaiset uskomustarinat: Tyypit ja motiivit. Suomalaisen Kirjallisuuden Seuran toimitteita 731. Helsinki: Suomalaisen Kirjallisuuden Seura. 
Klein 1967 = Клейн, Л. Пропала Бесиха! (О петроглифах Онежского озера). Уральский следопыт, 12, lk 40-47.

Koponen, Raija (peatoim) 1993. Karjalan kielen sanakirja 4. O-P. Lexica Societatis Finno-Ugricae $16_{4}$. Kotimaisten kielten tutkimuskeskuksen julkaisuja 25. Helsinki: Suomalais-Ugrilainen Seura.

Krušelnitskaja 1996 = Крушельницкая, Е. В. Автобиография и житие в древнерусской литературе. Санкт-Петербург: Наука.

Laugaste, E., Liiv, E. 1970. Muistendid Vanapaganast. Monumentae Estonia Antiquae III. Hiiu- ja vägilasmuistendid 3. Tallinn: Eesti Raamat.

Lauškin 1962 = Лаушкин, К. Д. Онежское святилище 2: Опыт новой расшифровки некоторых петроглифов Карелии. Скандинавский сборник 5, lk 177-298. Таллинн: Эстонское Государственное издательство.

Linevski 1939 = Линевский, А. М. Петроглифы Карелии 1. Петрозаводск: Каргосиздат. Mullo 1971 = Мулло, И. М. Памятники и памятные места Карелии. Петрозаводск: Карелия.

Oparin 1978 = Опарин, В. Хождение к Буян-камню. Петрозаводск: Карелия.

Petrov 1886 = Петров, К. Муромский Монастырь: (В Пудожском уезде). Олонецкий сборник 2, lk 99-117. Петрозаводск.

Poikalainen, Väino 2004. Rock Art of Lake Onega. Tartu, 2004.

Poikalainen, Väino, Ernits, Enn 1998. Rock Carvings of Lake Onega. The Vodla Region. Tartu: Estonian Society of Prehistoric Art.

Pomerantseva 1975 = Померанцева, Э. В. Мифологические персонажи в русском фольклоре. Москва: Наука.

Pulkin jt 1999 = Пулькин, М. В., Захарова, О. А., Жуков, А. Ю. Православие в Карелии (XV - первая треть XX в.). Москва: Круглый год.

Ravdonikas 1936 = Равдоникас, В. И. Наскальные изображения Онежского озера и Белого моря 1: Наскальные изображения Онежского озера. Москва, Ленинград: Издательство Академии наук СССР.

Sammallahti, Pekka 1989. Sámi-suoma sátnegirji. Saamelais-suomalainen sanakirja. Ohcejohka: Jorgaleaddji Oy.

Sawwatejew, Juri Alexandrowitsch 1984. Karelische Felsbilder. Leipzig: VEB E. A. Seemann Verlag.

Semjonov 1863 = Семенов, П. Географическо-статистический словарь Российской империи 1. Санкт-Петербург.

Severnõje 1978 = Северные предания. (Беломорско-Обонежский район). Издание подготовила Н. А. Криничная. Ленинград: Наука, 1978.

Slutševski 1897 = Случевский, К. К. По северу-западу России. Санкт-Петербург: A. Ф. Маркс.

Sreznevski 1989 = Срезневский, И. И. Словарь древнерусского языка $1_{1}$. Репринтное издание. Москва: Книга. 
Stoljar, Abram 2002. Muinaskarjala vaimuvara. Mäetagused. Hüperajakiri 17/18, lk 76-120.

Šaižin 1906 = Шайжин, Н. С. Старая Пудога с XIV по XVIII век: (историко-бытовой очерк). Петрозаводск.

Šved 1850 = Швед, П. Крестовый и Пели мысы. Географические известия, издаваемые Императорским Географическим обществом, 1, lk 68-71.

Šaparova 2001 = Шапарова, Н. С. Краткая энциклопедия славянской мифологии. Москва: Астрель Русские словари.

Šidlovski 1914 = Шидловский, А. Ф. Доисторические памятники на восточном берегу Онежского озера. Известия Общества изучения Олонецкой губернии $3_{1-2}, \mathrm{lk}$ $1-10$.

Zelenin 1991 = Зеленин, Д. К. Восточнославянская этнография. Москва: Главная редакция восточной литературы.

Tolstoi 1995 = Толстой, Н. И. (toim). Славянские древности. Этнолингвистический словарь 1. Москва: Международные отношения.

Vlassova 1998 = Власова, Марина. Русские суеверия. Энциклопедический словарь. Санкт-Петербург: Азбука.

\section{Summary}

\section{Devils' Exploits on the Eastern Shore of Lake Onega}

\section{Enn Ernits}

Key words: rock art, Karelia, devil, legends, Christianity

The article discusses the link between rock-carvings of Lake Onega in one of their locations, Cape Besov Nos, and five legends about devils. These are mostly new interpretations of etiological legends. The stories describe the origin of a rock island near the cape and the birth of some petroglyphs (the giant anthropomorphic figure of Cape Besov Nos, and representations resembling sun and staff). The legends discuss the devils' conflict with Christianity, their flight and perdition. One legend contains the motif of how the devil may crawl into a vessel if it does not have a lid or a cross-sign made on it. The weakening of the association of the local population with petroglyphs and the influence of Christianity led to the identification of the giant anthropomorphic figure with devil and the belief that smaller figures were made by devils. The motif of a devil in a kvass vessel seems to share common elements with the hagiography of the first bishop of Novgorod (12th century), which was probably known also in the areas beyond Lake Onega. The article attempts to refute the chrestomatic view that the cross-sign on the anthropomorphic figure and a swan representation at Cape Besov Nos has been carved by monks of the Saviour Monastery of Murom in the 14th century or later, because the Besov village remained outside the sphere of influence of the said monastery. It is more likely that it was carved in the 16th century or later by the clergy of Shala and Nigizhma. 